https://doi.org/10.18485/iipe_conv_conf.2021.ch11

\title{
THE DEPLOYMENT OF TURKISH POWER IN THE BALKANS
}

\author{
Alexis Troude 1
}

\begin{abstract}
The Balkans have once again become the favourite playground of the big boys. While Russia and China are advancing their positions in the face of a wait-and-see Euro-Atlantic bloc in the region, Turkey is reviving a neo-imperial policy. The neo-Ottoman policy, conducted with a drumbeat by Recep Tayyip Erdoğan since the early 2010s in Southeast Europe, allows Turkey to strongly mark the territory. Beyond numerous bilateral military and diplomatic agreements and a very prominent military presence (Kosovo, Bosnia), a Turkish "soft power" is imposing itself in the Balkans. Indeed, we are witnessing an acceleration of official visits by the highest representatives of the Turkish state and the opening of numerous Turkish cultural centers, which are based on the prevalent philo-Turkism among the Muslim populations of the region. A final lever of Turkish power is based on the recent but rapid deployment of numerous Turkish companies, both in industry and infrastructure and in services, because the Balkans represent a well-trained production base with low wage costs.

In this context, we need to look at the motives and objectives of the Turkish advance throughout Southeast Europe.
\end{abstract}

\section{TURKISH DIPLOMACY AND NEO-OTTOMANISM IN THE BALKANS}

Did the premonitory book by Milena Nokovitch, "And the Ottoman Night Fell on Europe", published in 1985, announce the return of the Ottoman Empire to South-East Europe?

After the battles of Maritza in 1371 and Kosovo Polje in 1389, Suleiman the Magnificent seized Constantinople in 1453 and settled definitively in

\footnotetext{
${ }^{1}$ Professor, The University of Versailles, Versailles, France. troudealexis@gmail.com.
} 
Europe with the capture of Belgrade in 1521. For more than five centuries, until the national liberation struggles of the Balkan peoples and their hardwon independence (Greece in 1830, Serbia in 1878, and Bulgaria in 1908), the Sublime Porte imposed its political and administrative system, as well as its culture (language and Muslim religion), on all of Southeast Europe.

Following the fall of the USSR and the breakup of Yugoslavia, this Ottoman legacy will serve as a basis for President Erdogan to deploy intense diplomatic and cultural activity in the Balkans, still marked by the Turkish imperial imprint. In 2012, during a trip to Bosnia-Herzegovina, he said: "For me, Sarajevo counts as much as Trabzon and Diyarbakir."

The Ottoman Empire has thus left its mark on the Balkans with a very rich religious heritage (mosques, medresas, funduqs). Faced with the cultural offensive of Wahhabi Islam (Arabia) that has built 240 mosques in Kosovo alone in 15 years ${ }^{2}$, Turkey has taken the bull by the horns. That is why Ankara has in recent years accelerated its religious aid, financing the largest mosque in Kosovo, in Mitrovica (2 million euros) and the one in Tirana (30 million euros). By choosing symbolic places of European Sunni Islam, Turkey thinks it will quickly catch up and impose itself as a leading cultural power in the Balkans.

At the beginning of the 2010s, a Turkish soft power was set up in the Balkans. The Cooperation and Development Agency (TIKA), with its six offices, is the largest provider of aid in the Balkans. It finances the construction of schools and universities, but also takes an interest in heritage (such as the reconstruction of the Mostar bridge). ${ }^{3}$ More broadly, Turkish influence grows as a result of its cultural policy, which capitalises on a multi-secular Ottoman Islam. Out of twenty-three Turkish cultural centres in the world (Yunus Emre Institutes, YEE), no less than twelve centres are present in the Balkans, spreading the Turkish language and culture. ${ }^{4}$

\footnotetext{
2 Claire Levenson, "L' Arabie saoudite a transformé le Kosovo en repaire de djihadistes", SLATE 23 May 2016. http://www.slate.fr/story/118443/arabie-saoudite-transformekosovo-en-repaire-de-djihadistes

${ }^{3}$ An essential link in Turkish soft power, the Cooperation and Development Agency (TIKATürk İşbirliği ve Kalkınma Ajansı) takes care of the renovation of Ottoman heritage, such as bridges, mosques, and medresses. TIKA also deals with the help of the poorest people (microcredits, health).

${ }^{4}$ For Davutoğlu, power rests as much on strength as on the ability to influence public opinion. Language, belief, culture, and leisure draw the contours of a neo-Ottoman soft
} 
On the school level, schools financed by the Güllenist movement ${ }^{5}$ and developing a rigorous Sunni Islam have been built in Albania, Bosnia-Herzegovina in particular, but also in Kosovo, North Macedonia, and Romania. Religious education is not ostentatious, even if a certain conservatism often prevails (veiled female staff, canteens sometimes separated for boys and girls). Finally, more than 10 universities are financed and controlled by the Turkish government: in Albania (Epoka University), in Bosnia-Herzegovina (International Burch University and International University of Sarajevo), in Macedonia (International Balkan University), and in Montenegro (Mediterranean University).

\section{A GROWING ECONOMIC AND ENERGY INFLUENCE}

Erdogan's Turkey is making intense efforts on the economic front and is about to replace its competitors in the Balkans. Indeed, since Sarkozy claimed in 2015 that "to let Turkey think that it can enter the EU is a monumental mistake" 6 . In the end, Erdogan understood that he could only maintain a foothold in Europe by literally investing in his former sphere of influence. The masterstroke was to use the failure of the South Stream gas pipeline project

power. Modelled on the Confucius Institutes, the Yunus Emre centres are spread throughout the Balkans. Their geographical distribution reveals Ankara's target countries (two in Albania, three in Bosnia, one in Serbia, three in Kosovo, and three in Macedonia). Through these linguistic institutes, Turkey provides scholarships and trains students who will later be called upon to take on responsibilities.

Tancrède Josseran, "Regards français sur les relations turco-balkaniques", Kultura n¹64, Belgrade (Serbia), Fall 2019, pp. 215-230.

${ }^{5}$ The brotherhood of Imam Fethullah Gülen, who has been exiled in the United States since 1999, has existed for more than forty years. It is active in more than a hundred countries around the world. In France, it is the city of Pantin (93) that hosts the headquarters of multiple associations affiliated with Hizmet (the service, as its members call it). There are schools and educational support centers, an entrepreneurial federation, and a humanitarian foundation.

https://www.franceculture.fr/societe/la-repression-du-mouvement-guleniste-en-france

${ }^{6}$ During this broadcast on Europe 1, December 1, 2015, Nicolas Sarkozy proclaimed, "I persist and I sign! Turkey is in Asia Minor, it is not in Europe", at a time when the file on its hypothetical accession is revived since the large influx of migrants on the Old Continent. For the former head of state, "it is a mistake to lie and make the Turks believe that they can join Europe". "We must have close relations with Turkey, common interests with Turkey. But it should not be a member of the European Union." 
to rebound on the Turkish Stream project with his strategic partner Putin. The South Stream project died because of the pressure exerted by the EU on Bulgaria: in November 2014, its government declared that it no longer wanted Russian gas tubes. Putin then changed his tune and proposed to Erdogan building the "Turkish stream", which would pass through Turkey, Greece, and then Macedonia and Serbia. However, the EU exerts constant pressure on the countries of Southeast Europe to prevent the realisation of the Turkish stream. For a moment, proposals for a hypothetical "Eastern Ring", blackmail on Greece for credits, and other revisions of EU-US projects from the 1990s (TAP or TANAP) seemed to dissuade Gazprom from starting large-scale work.

Is this the announced end of the Turkey/West partnership? Erdogan is now testing the Europeans, knowing that more than $40 \%$ of their gas deliveries come from Asia. In this new Eastern Question, the Balkans have become the European centre of the Great Global Energy Game. At the end of 2019, the strategic alliance between Russia and Turkey seems, despite the resistance of the EU, to definitively occupy the terrain of Southeastern Europe. On September 18, 2019, the Bulgarian energy operator "Bulgartranz" and Saudi Arabia's "Arkad" signed an investment agreement that will extend "Turkish stream" in Europe. From 2020, the new "Turkish Stream" brings Russian gas to the Greek port of Alexandropouli; from Greece, the Tesla pipeline will irrigate several Balkan countries, while the Poseidon pipe will supply Italy ${ }^{7}$.

Relying on this strategic deployment, the state and Turkish companies have literally invested in the Balkans over the last ten years. Even if Bulgaria risks being a brake on the Turkish stream project, it must be noted that it is the leading country in the Turkish system in the Balkans - 14 billion in investments over 10 years and 5 billion in bilateral trade in 2018, with action

https://www.europe1.fr/politique/sarkozy-la-turquie-ne-doit-pas-etre-membre-delunion-europeenne-2629425

${ }^{7}$ Launched well before South Stream, the American Nabucco pipeline project, supported by the EU, was to supply Western Europe with gas from the Caspian Sea; its route passed through Turkey, Bulgaria, Romania, and Hungary. But in the face of competition from South Stream and the defection of Turkey and Azerbaijan in 2011, it was abandoned for a while. Faced with the EU's blockade of the South Stream project, the AmericanEuropean gas pipeline has been reborn from its ashes since 2014 under the name Nabucco-West, with almost the same route. 
in the fields of energy, health, and the electricity industry. Second, the grip on Muslim countries is equally important. Even if trade with BosniaHerzegovina and Kosovo remains limited, economic projects in these two predominantly Muslim countries have been accelerating in recent years. In Bosnia-Herzegovina, sections of the highway from the capital Sarajevo to Belgrade and Budapest have been entrusted to Turkish companies, and a project to modernise its airport is underway with Ankara. In Kosovo, Turkey is among the leading investors (38 million euros per year), which has allowed banks, such as TEB, İş Bankası and Ziraat, but also the wind and electrical industries to establish themselves in this small state.

Finally, in other nations where the Muslim population forms a significant community, Turkish companies are doing everything possible to establish a presence. In the last five years, their number has risen from 29 to 1,545 in Montenegro, and real estate and airport investments are all over the place (Vlorë in Albania and Skopje and Ohrid in northern Macedonia). Even the steel industry is targeted, with the purchase of the Nikšić steelworks in Montenegro by Tosyali. But it is in Serbia that the economic conquest operation has been strongest. However, in a country that was liberated from the Ottoman yoke in the 19th century, the game was not won in advance. One also remembers the provocative words of Recep Tayyip Erdoğan, then Turkish Prime Minister, who declared, during an official visit to Priština in October 2013, "Turkey is Kosovo, and Kosovo is Turkey". But times have changed, and thanks to a very cordial understanding between Erdogan and Vučić, many economic agreements between Turkey and Serbia could be signed. There are now no fewer than 800 Turkish companies in Serbia, and trade has increased fivefold since $2010^{8}$. More broadly, after Erdogan's last official visit to Serbia in October 2019, an Ankara-Belgrade-Sarajevo axis is taking shape. Bringing together these three countries, a "Trade Committee" was formed in 2013 and a free trade zone in August 2015. The October 2019 agreement provides for trade relations between Serbia and the two Muslim nations. We can see that

\footnotetext{
${ }^{8}$ With 135 million euros of FDI still in 2019, the Turks have established themselves in the textile and automotive industries. A new Free Trade Agreement was signed in January 2019; there will be no more tariffs on Serbian products exported to Turkey. The economic consequences were quickly felt, with Serbian agricultural exports increasing in exchange for Turkish textile imports and car parts.
} 
Erdogan uses the commercial lever in order to recreate a free trade zone in the historical backyard of Turkey.

\section{REPOSITIONING OF TURKEY AS A MAJOR REGIONAL PLAYER}

With a view to curbing migration flows to Europe, on March 18, 2016, an agreement was signed between the EU and Turkey. The EU pays 6 billion euros (aid to refugee camps) and places Turkey in the EU's antechamber, revitalising the accession process and lifting visas for Turkish citizens, in order to "fix" at least temporarily 4 million refugees and other candidates for departure to the West on Turkish soil. But despite this agreement, the result of the EU's migration policy is distressing. In 2017, out of 160,000 asylum applications filed in Italy and Greece, only a few hundred could be honored; only 20,000 refugees out of 856,000 from Turkey could be settled in other European countries 9 .

Turkey seems to be waving the red rag again at the end of 2019 because the March 2016 agreement seems insufficient. The EU should increase the sums distributed to Turkey in the new European migration agreement, Dublin IV; already, Greek Prime Minister Kyriakos Mitsotakis urged, on the UN podium in late September 2019, that the European funds distributed to Turkey increase "in order to limit the flows in Europe." Indeed, more than 70,000 migrants were on Greek soil at the end of 2019, causing riots and deaths in transit camps ${ }^{10}$.

\footnotetext{
${ }^{9}$ The EU has reinforced Frontex assistance there in logistics and human resources, but despite this, the Greek authorities are criticised for their "serious failures in border enforcement. The aim of the EU was still, in mid-January, in Greece, to close the external borders of the EU to "allow free movement in the EU." However, by the end of January 2017, the EU had changed its tune: if Greece fails in its policy of retention of migrants and border control, a Recommendation decided by the European Commission proposes the introduction of re-establishing control, for two years at most, at some internal borders.

Cécile Ducourtrieux, from the newspaper "Le Monde", says it clearly: "The Union seems incapable of managing in a coordinated way projects that it has itself elaborated, such as the relocation of 160,000 refugees". As Turkey, involved in the war with Syria, does not seem to apply the agreements of November 28, 2016 (Erdogan even declared on January 21, 2017 that "we cannot create an open-air prison"), the EU is betting everything on Greece. The latter welcomed more than a million migrants in 2015.

${ }^{10}$ Alexia Kefalas, “La Grèce de nouveau débordée par les migrants”, Le Figaro, I October 2019. In the camp of Moria on the island of Lesbos, a fire caused the death of three people following a fire on September 29, 2019. This camp hosts more than 13,000 refugees,
} 
The geopolitics of the Middle East will once again have an impact on the migration issue in Europe. Furious about the setbacks suffered on the military front in Syria, Turkish President Recep Erdogan decided at the end of February 2020 to open the migration floodgates wide: "We have opened the doors. Why? Because the EU had to keep its promises."11

As early as February 27, 2020, 37,000 migrants were sent to the Greek border in one day; it was learned that the Moria refugee camp on the Greek island of Lesbos, built to accommodate 3,000 people, had been housing more than 20,000 for years. Yet the Greek president, Kyriakos Mitsotakis, reacted by claiming that "it is no longer a question of refugees: it is a clear attempt by Turkey to use poor people to promote its own political agenda" ${ }^{12}$. These migrants of Syrian, Afghan, or Kurdish origin want to enter the EU at all costs, to flee the war or simply to have a better life, dreaming of an idealised Europe $^{13}$. For the moment, the Greek authorities have managed to push them back, at the cost of repressive measures, but until when?

Tired of waiting for possible EU membership, Turkey has used the Balkans to put pressure on the EU. Indeed, having started its accession process at the same time as Croatia, the latter has already been a full member of the EU for 7 years and has already held the presidency once, while Turkey has seen its accession, requested in 1963 from the defunct EEC, postponed to the Greek calendar. President Edogan has skilfully surfed on a certain nostalgia for the Ottoman Empire to impose the imprint of modern Turkey on the Balkans.

four times its capacity. More than 1,000 migrants arrived each week in the Aegean islands in the fall of 2019, and in early 2020, more than 70,000 migrants were on Greek soil, causing riots and deaths in transit camps.

${ }^{11}$ Delphine Minoul, "Erdogan is a master of migratory blackmail," Le Figaro, 3 March 2020. Report, "Les migrants lâchés par la Turquie," France info TV, March 1, 2020.

${ }^{12}$ A.F.P. and Reuters, "Turkey: thousands of migrants flock to the Greek border", Le Figaro, 1 March 2020. https://www.lefigaro.fr/international/turquie-des-milliers-de-migrantsaffluent-a-la-frontiere-grecque-20200301

${ }^{13}$ Habiya, a Kurd from Iran interviewed at the Greek-Turkish border, says: "We dream of a better life, where our children will have the right to free health care and education. So why do you refuse to let us pass?".

Cyrille Louis, "A la frontière turco-grecque, un 'exode' téléguidé," Le Figaro, March 3, 2020 
Bosnia-Herzegovina is at the heart of this strategic device: the Izetbegovi clan, father (Alija) and son (Izet), has been at the helm of the country since the early 1990s, and has made a point of basing its legitimacy among its Bosniak electoral clientele on the Ottoman Empire's heritage and grandeur. For his part, we remember that Erdogan said in 2012, during a trip to BosniaHerzegovina, "For me, Sarajevo counts as much as Trabzon and Diyarbakir. Bosnia-Herzegovina is the most faithful ally of Sunni Turkey, with a rapid Islamization of society visible in the streets of Sarajevo ${ }^{14}$.

But Erdogan's Turkey has also been able in recent years, in a competition with Shiite Saudi Arabia, to accelerate its footprint on the other Muslim nations of the region. Erdogan is very close to Albanian President Edi Rama, who describes his Turkish alter ego as a "great friend" of Albania; in Kosovo, the Turkish contingent of KFOR is present in Metohia (the western region), and has proved to be the perfect policeman between the various Muslim minorities (Turks, Bosniak, and Goranis). More broadly, Turkish security services are increasingly active in North Macedonia and western Kosovo.

\section{CONCLUSION}

The clock seems to have turned in the Balkans. Europeans are concerned that Turkey's actions will limit the EU's influence in the region. Thus, on May 17, 2018, the EU did not invite Turkey to the EU-Western Balkans summit; it thus showed its desire to be the sole actor in the enlargement process of the 6 Balkan countries invited (Bosnia-Herzegovina, Montenegro, Serbia, Albania, Kosovo, Macedonia).

At a time when Turkey is gradually moving away from the prospect of EU membership and is drawing closer to the powers that matter in the region, such as Russia and Iran, its influence in the Balkans is not well perceived by its Western partners. European leaders have procrastinated too much by never giving Turkey a real deadline, either out of fear of the Islamization of

\footnotetext{
${ }^{14}$ Bosnian Muslims, of Ottoman Sunni tradition, have been undergoing a process of Islamist radicalization in society for two decades. The streets of the capital are becoming more and more crowded with young people wearing long beards and Salafist quami. The bars serve less and less beer, and the Accor hotel is "halal". See Bernard de la Villardière, "Bosnia, Serbia, Kosovo, the new territories of radical Islam", "Exclusive Investigation", M6, April 29, 2018.
} 
the continent or, more broadly, because Turkey does not share the same values (Kurdish question, annexation of the TRNC). However, by leaving the Balkans as a buffer zone for foreign ambitions, the EU and the US have played with fire, and it will be difficult to make up for lost time. Faced with the conquering geopolitics of China, Russia, and Turkey in this region of Europe, Western powers must do everything possible to maintain their waning influence in the heart of the continent. 